\title{
Effects of toxic cyanobacteria on a plankton assemblage: community development during decay of Nodularia spumigena
}

\author{
Jonna Engström-Öst ${ }^{1,2, *}$, Marja Koski ${ }^{2,3, * *}$, Katrin Schmidt ${ }^{4}$, Markku Viitasalo ${ }^{1}$, \\ Sigrún H. Jónasdóttir ${ }^{5}$, Marjaana Kokkonen ${ }^{3}$, Sari Repka ${ }^{6}$, Kaarina Sivonen ${ }^{6}$ \\ ${ }^{1}$ Finnish Institute of Marine Research, PO Box 33, 00931 Helsinki, Finland \\ ${ }^{2}$ Tvärminne Zoological Station, J. A. Palménin tie 260, 10900 Hanko, Finland \\ ${ }^{3}$ Department of Ecology and Systematics, Division of Hydrobiology, PO Box 65, University of Helsinki, \\ 00014 Helsinki, Finland \\ ${ }^{4}$ Baltic Sea Research Institute, Seestrasse 15, 18119 Rostock, Germany \\ ${ }^{5}$ Danish Institute for Fisheries Research, Department of Marine Ecology and Aquaculture, Kavalergården 6, \\ 2920 Charlottenlund, Denmark \\ ${ }^{6}$ Department of Applied Chemistry and Microbiology, Division of Microbiology, PO Box 56, University of Helsinki, \\ 00014 Helsinki, Finland
}

\begin{abstract}
We studied the development of the plankton community in an artificially created toxic Nodularia spumigena bloom during a $2 \mathrm{wk}$ enclosure study at the SW coast of Finland in the Baltic Sea. We measured bacterial abundance, dominant phytoplankton groups and ciliates, as well as concentrations of phytoplankton pigments, fatty acids, nodularin, protein and nutrients. A high POC:chl a $(<10 \mu \mathrm{m})$ ratio $(427 \pm 185)$, a decrease in the polyunsaturated:total fatty acid ratio (from 0.4 to 0.2 ), and a reduction in cyanobacteria filament length indicated decay of $N$. spumigena during the course of the experiment. Along with cyanobacterial decay, high concentrations of ammonium (last day: $2.7 \pm 2.0 \mu \mathrm{mol} \mathrm{l} \mathrm{l}^{-1}$ ), nitrate $\left(0.1 \pm 0.01 \mu \mathrm{mol} \mathrm{l} \mathrm{l}^{-1}\right)$, and organic nutrients were released into the water, whereas chl $a$ and the cyanobacterial pigments, echinenone and zeaxanthin, decreased. Nodularin was found in the mesocosms during the whole experiment. A strong increase in filamentous bacteria was detected by the middle of the experiment, most likely indicating a response to grazing pressure. Two ciliate species, Mesodinium rubrum and Urotricha sp., decreased dramatically during the experiment, probably due to predation by the increasing mesozooplankton community. The ciliate Euplotes sp. flourished in the bags and was best suited to escape predation due to its protecting lorica and its surface affinity. No direct harmful effects of the cyano-bacteria on the microorganisms could be documented. We conclude that these blooms provide a potential food source for the heterotrophic food chain, from bacteria, flagellates and ciliates to crustacean zooplankton, and possibly fish.
\end{abstract}

KEY WORDS: Nodularia spumigena $\cdot$ Decay $\cdot$ Bacteria $\cdot$ Fatty acids $\cdot$ Nodularin $\cdot$ Ciliates

\section{INTRODUCTION}

Fossil records show that the first cyanobacterial blooms appeared ca. 7000 years ago in the Baltic Sea

\footnotetext{
*E-mail: jonna.engstrom-ost@fimr.fi

** Present address: Netherlands Institute for Sea Research, PO Box 59, 1790 AB Den Burg, Texel, The Netherlands
}

(Bianchi et al. 2000). Resistance of zooplankton to algal toxins has been documented several times (Hanazato \& Yasuno 1987, Fulton 1988) and could have evolved also in the Baltic ecosystem. Besides producing toxins, cyanobacteria also show allelopathic and antibiotic activities (Østensvik et al. 1998, Pushparaj et al. 1999) that may be harmful to phytoplankton and bacteria. 
The carbon flow in the planktonic food webs of the Baltic Sea is well studied (Lignell et al. 1993, Uitto et al. 1997), as are the spatial and temporal dynamics of the cyanobacterial mass-occurrences (Kononen et al. 1999, Bianchi et al. 2000) that are common phenomena especially during warm summers. In contrast, few attempts have been made to study the fate of a decaying cyanobacterial bloom and its effects on other organisms of the pelagic ecosystem. A large part of the diatom spring bloom at higher latitudes settles to the bottom (Wassmann \& Slagstad 1993), whereas knowledge about the fate of the cyanobacterial bloom is contradictory. Some studies have concluded that sedimentation and grazing are negligible in the Baltic Sea (Heiskanen \& Kononen 1994, Sellner 1997), whereas in other studies, grazing is considered important (MeyerHarms et al. 1999, Rolff 2000).

One of the most important bloom-forming cyanobacteria species in the Baltic Sea is Nodularia spumigena (Kahru et al. 1994, 2000). Several characteristics of $N$. spumigena make it an interesting study object. Cyanobacteria are strong competitors for e.g. phosphorus, nitrogen (Mur et al. 1999), and light (Ibelings \& Maberly 1998). Further, N. spumigena is toxic and has gas vacuoles (Mur et al. 1999), which operate even in dead cells (reviewed by Sellner 1997). Therefore, an ageing $N$. spumigena bloom has been suggested to resist sedimentation and to decay within the water column (Heiskanen \& Kononen 1994, Sellner 1997). Heinänen et al. (1995) found that an ageing cyanobacterial bloom provided elemental substrates for bacteria, whereas the young and growing Nodularia filaments seldom were colonised by any organisms. Further, it has been shown that decaying cyanobacterial blooms are diverse biotopes colonised by bacteria, protozooplankton, flagellates and crustaceans (Hoppe 1981).

The purpose of this study was to investigate the plankton community development in an artificial cyanobacteria bloom, created by adding a high concentration of cultured toxic Nodularia spumigena to a $<100 \mu \mathrm{m}$ filtered natural plankton community. The study was performed in mesocosm bags in July 1999. Over a period of $2 \mathrm{wk}$, we monitored the mesocosm bags by measuring organism abundances, chl $a$, toxin, nutrient, protein, fatty acid and phytoplankton pigment concentrations. In this paper, we analyse and discuss the effects of the decaying bloom on the plankton community and the interactions between different organism groups and the factors controlling them.

\section{MATERIALS AND METHODS}

Nodularia spumigena culture, experimental set-up and sampling. The toxic Nodularia spumigena strain
(AV1) was obtained from the Division of Microbiology, University of Helsinki (Lehtimäki et al. 1994, 2000) and grown in a modified $\mathrm{Z} 8$ medium at $\sim 6.8 \mu \mathrm{E} \mathrm{m} \mathrm{m}^{-2} \mathrm{~s}^{-1}$ (Hughes et al. 1958, Kotai 1972). The light was measured with the LICOR-1000 irradiance meter. Five litre batch cultures were grown at $18^{\circ} \mathrm{C}$ in a $16 \mathrm{~h}$ light: $8 \mathrm{~h}$ dark cycle and supplied with air. The cyanobacteria concentration was determined spectrophotometrically using a calibration curve of extinction versus carbon concentration, which was derived from chemical oxygen demand measurements (Gulati et al. 1991).

We set up five $120 \mathrm{l}$ mesocosm enclosures in a sheltered bay, characterised by upwelling (Niemi 1975). The transparent polyethylene enclosures (thickness: $150 \mu \mathrm{m})$ were double and their collars mounted on a wooden rack (Kivi et al. 1993). The bags were filled with $100 \mu \mathrm{m}$ filtered seawater collected from a nearby pelagic area (Tvärminne Zoological Station, Baltic Sea, $\left.59^{\circ} 51^{\prime} \mathrm{N}, 23^{\circ} 15^{\prime} \mathrm{E}\right)$. The monoculture of Nodularia spumigena was filtered using a $20 \mu \mathrm{m}$ mesh size net, and added to 4 bags at a concentration of $460 \mu \mathrm{g} \mathrm{C} \mathrm{l}^{-1}$. $N$. spumigena culture was not added to one of the bags which was kept as a control. All bags were kept in normal daylight and covered with transparent polyethylene. During the 2 wk experiment (2 to 14 July 1999), temperature was measured daily, samples for bacteria, phytoplankton, ciliate and chl a measurements were collected daily; and samples for pigment, fatty acid (from 7 July 1999 onwards), total nodularin, protein, and particulate and dissolved nutrient measurements were collected every second or third day. The bags were mixed before sampling.

Analyses. Bacterial cell counts were made according to Hobbie et al. (1977) and Autio (1998): $1 \mathrm{ml}$ was stained with acridine orange. At least 20 fields and 200 cells were counted with a Diaplan microscope using $12.5 \times$ oculars and $100 \times$ magnification. The cells were divided into 5 morphotypes according to average sizes and morphology: cocci (no size limit), vibroid-like bacteria (no size limit), short rods (1.5 to $10 \mu \mathrm{m})$, mediumsized rods (10 to $50 \mu \mathrm{m}$ ) and long rods (50 to $130 \mu \mathrm{m})$. A total of 100 cells, randomly selected, were measured at the beginning and the end of the experiment. The cell volumes $\left(\mu^{3}\right)$ were calculated according to the formula $(\pi / 4) W^{2}(L-W / 3)$ where $L$ is length and $W$ is width (Fuhrman 1981).

For chl a analysis, 2 parallel $100 \mathrm{ml}$ samples were filtered on glass-fibre filters (Whatman GF/F), sonicated and extracted in $96 \%$ ethanol for $24 \mathrm{~h}$ in darkness. Chl a was analysed for 3 size fractions (total, $<20 \mu \mathrm{m},<10 \mu \mathrm{m}$ ) and measured with a Shimadzu spectrofluorometer.

Subsamples (200 to $500 \mathrm{ml}$ ) were filtered on Whatman GF/F filters and stored at $-20^{\circ} \mathrm{C}$ for pigment analyses with HPLC. The frozen filters were extracted in 
$3 \mathrm{ml} \mathrm{100 \%}$ methanol buffered with $2 \%$ ammonium acetate by sonication and centrifugation. An aliquot $(300 \mu \mathrm{l})$ of the extract was injected into an RSil $\mathrm{C}_{18}$ column $(150 \times 4.6 \mathrm{~mm}$, Bio-Rad RSL $)$. The photosynthetic pigments of different phytoplankton groups were separated at a flow rate of $1 \mathrm{ml} \mathrm{min}^{-1}$ by a linear gradient programmed as follows (minutes, \%solvent $\mathrm{A}$, \% solvent $B, \%$ solvent $C):(0,100,0,0),(4,0,100,0),(18,0$, $20,80),(21,0,100,0),(24,100,0,0)$ and $(29,100,0,0)$. The instrument used was a Merck-Hitachi liquid chromatograph equipped with an L6200A gradient pump with system controller (interface module D-600), a photodiode array detector (L4500), and an F-1050 fluorescence spectrophotometer. Pigment detection was done at $436 \mathrm{~nm}$ for all chlorophylls and carotenoids. The HPLC system was calibrated with pigment standards from the International Agency for ${ }^{14} \mathrm{C}$ Determination, Denmark. Pigments were identified by retention time and comparison of on-line collected absorption spectra (between 300 and $700 \mathrm{~nm}$ ) with those of the pigment standards in the spectral library.

Phytoplankton and ciliates were determined from a $100 \mathrm{ml}$ sample preserved with acid Lugol's solution. Cells were counted in cuvettes with a Leitz Labovert microscope using $10 \times$ oculars and $25 \times$ objectives for ciliates, and $40 \times$ objectives for phytoplankton (Utermöhl 1958). At least 500 flagellates (Chrysochromulina sp., Pyramimonas sp., cryptophytes), and 300 filaments of Nodularia spumigena were counted per cuvette. Less abundant diatoms, dinoflagellates and other cyanobacteria were counted in 20 to 60 eye-fields, depending on the cell density.

Fatty acids were measured to get an estimate of the chemical composition of the bloom during decay. For analysis, 1 sample of 200 to $500 \mathrm{ml}$ was filtered on combusted GF/F (Whatman) filters, placed into Eppendorf tubes, flushed with nitrogen gas and stored at $-80^{\circ} \mathrm{C}$. Lipids were extracted from the filters for $24 \mathrm{~h}$ in $\mathrm{CH}_{2} \mathrm{Cl}_{2}$-methanol $(2: 1, \mathrm{v} / \mathrm{v})$ with a known amount of $\mathrm{C}_{17}$ fatty acid added to the sample. The fatty acids were transmethylated with $\mathrm{BF}_{3}$-methanol to form fatty acid methyl esters (FAME). The fatty acids were analysed by gas chromatography on a capillary column. The FAME sample was injected into a gas chromatograph (Hewlett Packard 5890A) with splitless injection using

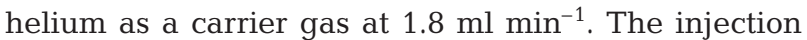
temperature was $+200^{\circ} \mathrm{C}$. The temperature program

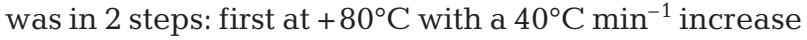
to $+160^{\circ} \mathrm{C}$ where it stayed isothermal for $1 \mathrm{~min}$, and then with an increase from $+160^{\circ} \mathrm{C}$ to $+220^{\circ} \mathrm{C}$ at $3^{\circ} \mathrm{C}$ $\mathrm{min}^{-1}$ where it remained isothermal for $17 \mathrm{~min}$. Peaks from chromatograms were compared with Sigma and Larodan FAME standards for specific fatty acid identification and the integrated peaks compared with the peak area of the $\mathrm{C}_{17}$ standard.
Nodularin, the hepatotoxin produced by Nodularia spumigena, was measured in order to get an estimate of cyanobacteria biomass and to observe its potential harmful effects on the plankton. Nodularin is known to correlate strongly with $N$. spumigena cell numbers (Heresztyn \& Nicholson 1997). The total concentration in mesocosms was determined by extracting the nodularin directly from 11 of water by sonicating twice for 15 min (Braun Labsonic-U) and freezing and thawing twice. The remaining cell material was removed by filtering with GF 52 glass-fibre filters (Schleicher \& Schuell). The filtrate was concentrated on C-18 cartridges (Oasis, Waters). The cartridges were washed with $5 \mathrm{ml}$ of $20 \%$ methanol prior to elution with $2 \mathrm{ml}$ of $100 \%$ methanol. The samples were dried in an air stream and dissolved in $0.5 \mathrm{ml}$ of $20 \%$ methanol. Nodularin was analysed with a Hewlett-Packard HP1090 liquid chromatograph equipped with a Hewlett-Packard UV/VIS diode array detector and Hewlett-Packard ODS Hypersil column (100 mm $\times$ $4.6 \mathrm{~mm})$. The mobile phase was a 77:23 mixture of $10 \mathrm{mM}$ ammoniumacetate buffer and acetonitrile. Flow rate was $1 \mathrm{ml} \mathrm{min}^{-1}$, injection volume $25 \mu \mathrm{l}$, and detection at $238 \mathrm{~nm}$. Nodularin was identified by its retention time and UV-spectrum. Purified nodularin was used as a reference.

Ammonium $\left(\mathrm{NH}_{4}{ }^{+}\right)$, nitrate $\left(\mathrm{NO}_{3}{ }^{-}\right)$, total nitrogen, phosphate $\left(\mathrm{PO}_{4}^{-}\right)$and total phosphorus were analysed according to Koroleff (1979). DON was analysed similarly as total nitrogen (Koroleff 1979), after the sample had been filtered through acid-washed and precombusted $\left(450^{\circ} \mathrm{C}\right)$ Whatman $(\mathrm{GF} / \mathrm{F})$ glass fibre filters. POP was analysed according to Solórzano \& Sharp (1980). For POC, PON and POP, all glassware and glass fibre filters (Whatman GF/F) were acid-washed, and filters precombusted $\left(450^{\circ} \mathrm{C}\right)$. POC and PON analyses were measured with a mass spectrometer (Europa Scientific Roboprep and Tracermass).

Protein analysis was measured to get an estimate of the chemical composition of the bloom according to Herbert et al. (1971).

Statistical analysis. We used principal component analysis (PCA) in order to find out which variables correlated best with cyanobacteria added to the mesocosms. The reason for using PCA was to obtain the interrelationship between the high number of variables included in this study. PCA identifies principal components of which the first one consists of a linear combination of the original variables and reflects the correlation between them, whereas the second one consists of the remaining information, unrelated to the first one. PCA does not make any a priori assumptions about the relationships among variables. A score higher than 0.6 on a component indicates moderate significance, whereas scores higher than 0.7 indicate high significance (Meglen 


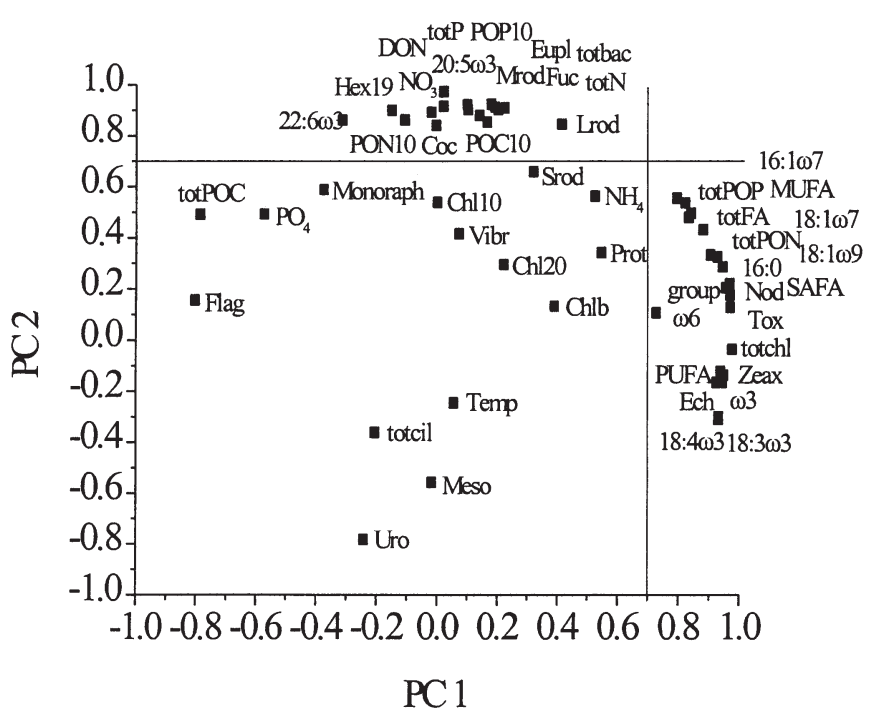

Fig. 1. Biplot of variables analysed with principal component analysis (PCA) for the total data. Loadings above \pm 0.7 , shown with a line on both axes, indicate substantial to high relationships. See 'Results' for interpretations of components. Group: control vs treatment, Temp: temperature, Flag: flagellates, Nod: Nodularia spumigena, Monoraph: Monoraphidium contortum, Uro: Urotricha sp., Eupl: Euplotes sp., Meso: Mesodinium rubrum, Totcil: total ciliates, Coc: cocci, Srod: short rods, Mrod: medium-sized rods), Lrod: long rods, Vibr: vibroid-like bacteria, totbac: total bacteria, totchl: total chlorophyll $a$, Chl10: chlorophyll $a<10 \mu \mathrm{m}$, Chl20: chlorophyll a $<20 \mu \mathrm{m}$, Tox: nodularin, NH4: ammonium, $\mathrm{NO}_{3}$ : nitrate, totN: total nitrogen, $\mathrm{PO}_{4}$ : phosphate, totP: total phosphorus, totPON: total particulate organic nitrogen, PON10: PON $<10 \mu \mathrm{m}$, totPOP: total particulate organic phosphorus, POP10: POP $<10 \mu \mathrm{m}$, totPOC: total particulate organic carbon, POC10: POC $<10 \mu \mathrm{m}, \mathrm{DON}$ : dissolved organic nitrogen, Prot: protein, Ech: echinenone, Chlb: chlorophyll $b$, Zeax: zeaxanthin, hex19: 19'-hexanoyloxyfucoxanthin, Fuc: fucoxanthin, SAFA: saturated fatty acids, MUFA: monounsaturated fatty acids, PUFA: polyunsaturated fatty acids, totFA: total fatty acids, $\omega 3$ : $\omega 3$-series of PUFA, $\omega 6$ : $\omega 6$-series of PUFA

1992). Data were log transformed in order to homogenise variance. All data were not normally distributed, but PCA should be robust concerning slight deviations from normality (Mayzaud et al. 1989). The PCA was run with Varimax rotation, indicating that the sum of variances is maximised of loadings in the factor matrix (Hair et al. 1998). Conventional statistical methods such as correlation analysis or repeated-measures ANOVA were not applicable in this case, due to the unreplicated control and the large number of variables.

\section{RESULTS}

We interpreted that the first principal component (PC 1) was strongly associated with the added Nodularia spumigena and associated characteristics: total chl $a$, nodularin, total PON and POP, the cyanobacterial pigments echinenone and zeaxanthin, saturated fatty acids (SAFA), monounsaturated fatty acids (MUFA), polyunsaturated fatty acids (PUFA), $\omega 3$ PUFA-series and total fatty acids (FA), and 16:0,

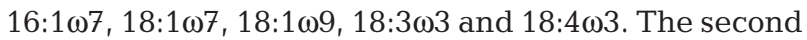
component (PC 2) was closely related to processes that showed similar dynamics in both the control and the treatment, including the ciliate Euplotes sp., cocci, medium-sized rods, long rods and total bacteria, $\mathrm{NO}_{3}{ }^{-}$, total $\mathrm{N}$ and P, PON, POP and POC $(<10 \mu \mathrm{m}), \mathrm{DON}$, the pigments 19'-hexanoyloxyfucoxanthin, fucoxanthin

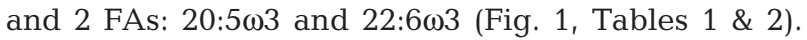
The first 2 components ex-plained $74 \%$ of the total variance; hence no other components are discussed. All dynamics described below are based on the PCA.

\section{Bloom decay}

Cyanobacteria started to decay already by the middle of the experiment. The filaments were observed under the microscope and they were in poor condition; the cells were transparent and covered by epifauna and flora. Several of the measured parameters indicated bloom decay. The filament length of Nodularia spumigena decreased significantly (Kruskal-Wallis 1-way ANOVA, $\mathrm{H}_{2,299}=9.9, \mathrm{p}<0.01$ ) between the first and the last day of the experiment, from $288 \pm 267$ to $158 \pm 89 \mu$ m (mean \pm $\mathrm{SD}, \mathrm{n}=100)$. The POC:chl $\mathrm{a}(<10 \mu \mathrm{m})$ ratio was 427 by the end of our study (Fig. 2A). The PUFA:total FA ratio was significantly lower in the end than in the middle of the study (Mann-Whitney $U$-test, $U=2.2, \mathrm{n}_{1}=4, \mathrm{n}_{2}=4$, $\mathrm{p}<0.05$; Fig. 2B). Total chl $a$ and the cyanobacterial pigments, echinenone and zeaxanthin decreased strongly towards the end of the experiment (Fig. 2C,D,E). $\mathrm{NH}_{4}{ }^{+}$ increased towards the end of the experiment (Fig. 2F). On the other hand, the development of total nodularin and protein concentrations did not indicate bloom decay because total nodularin was quite stable throughout the experiment (Fig. 2G), whereas protein varied a lot (data not shown).

\section{Succession in the enclosures}

The average temperature fluctuated at $15.6 \pm 1.6^{\circ} \mathrm{C}$ during the experiment due to upwelling of cold water in the bay where the enclosures were situated (data not shown).

The abundance of different bacteria, total bacteria, cocci, vibroid-like bacteria and short rods was lowest during the middle of the experiment (Fig. 3A to D). Filamentous bacteria such as medium-sized and long rods became more abundant from 10 July onwards 
Table 1. Diagnostic pigments for characterisation of the different algal groups (Millie et al. 1993, Meyer-Harms \& von Bodungen 1997) and the main species recorded in the mesocosm bags

\begin{tabular}{|ll|}
\hline Phytoplankton marker pigment & Autotrophic groups and main species \\
\hline Zeaxanthin and echinenone & $\begin{array}{l}\text { Cyanobacteria: Nodularia spumigena, } \\
\text { Anabaena sp., Aphanizomenon flos- } \\
\text { Fucoua, Limnothrix sp. }\end{array}$ \\
& $\begin{array}{l}\text { Chrysophytes: Pseudopedinella sp. } \\
\text { Spiniferomonas sp., Uroglena sp. }\end{array}$ \\
& Diatoms \\
& Dinoflagellates \\
& Prymnesiophytes: Chrysochromulina sp. \\
& Dinoflagellates \\
& Prymnesiophytes: Chrysochromulina sp. \\
Chl $b$ & Chlorophytes: Monoraphidium contortum \\
& Euglenophytes: Pyramimonas sp. \\
Alloxanthin ${ }^{\text {a }}$ & Prasinophytes \\
apigment not recorded in HPLC, & Cryptophytes \\
countings &
\end{tabular}

especially in the cyanobacteria bags (Fig. 3E,F). The average cell volumes of the different bacterial morphotypes at the end of the experiment were $1.4 \pm 2.1 \mathrm{um}^{3}$ (cocci + vibroid-like bacteria), $2.7 \pm 1.3 \mu^{3}$ (short rods), $9.1 \pm 4.3 \mu^{3}$ (medium-sized rods), and $21.0 \pm$ $12.0 \mathrm{\mu m}^{3}$ (long rods). Bacterial volume in the treatment enclosures was significantly higher at the end than at the beginning of the experiment (Mann-Whitney $U$, $z=10.5, \mathrm{n}_{1}=100, \mathrm{n}_{2}=100, \mathrm{p}<0.0001$ ).

Among the different measured pigments, there was no trend to be found in chl $a(<10$ and $<20 \mu \mathrm{m})$ and chl $b$ (Fig. 4A,B,C), whereas fucoxanthin and 19'-hexanoyloxyfucoxanthin showed high scores on PC 2, indicating that these pigments developed in the same manner in all enclosures (Fig. 1). Fucoxanthin and 19'-hexanoyloxyfucoxanthin concentrations increased in all bags towards the end of the experiment (Fig. 4D,E).

The number of Nodularia spumigena filaments in the enclosures showed a varying pattern, but a slight decrease was to be detected at the end of the study (Fig. 5A). Flagellates were significantly less abundant in the cyanobacteria bags than in the control (Fig. 5B), and were strongly negatively associated with $N$. spumigena (Fig. 1). Heterotrophic flagellates were not counted during the study. The green alga Monoraphidium contortum did not show any clear pattern during the study (Fig. 5C, Table 1). Among the dominant groups of ciliates, 2 patterns could be distinguished: Euplotes sp. increased fast in number from 10 July onwards in the cyanobacteria bags (Fig. 5D), whereas Mesodinium rubrum and Urotricha sp. (10 to
$40 \mu \mathrm{m})$ declined and almost disappeared from all en-closures by the end of the experiment (Fig. 5E,F). By the end of the experiment, Urotricha sp. increased slightly again. No particular trend was ob-served for Strombidium sp. and Strombilidium sp. (data not shown). Total ciliates showed a varying pattern and were not associated closely with any component (Fig. 1). In the end, the total number of ciliates increased rapidly (Fig. 5G).

Mesozooplankton abundance and composition are discussed in detail in K.S. et al. (unpubl.). In short, copepodites and adults of the copepod Eurytemora affinis were on average found at 10 ind. $\mathrm{l}^{-1}$ at the end of the experiment, whereas the number of copepodites and adults of Acartia bifilosa was negligible $\left(<1\right.$ ind. $\left.\mathrm{l}^{-1}\right)$. The abundances of the rotifers Synchaeta spp. (5 to 90 ind. $\mathrm{l}^{-1}$ ) and Keratella spp. $\left(<10\right.$ ind. $\left.\mathrm{l}^{-1}\right), E$. affinis nauplii (10 to 50 ind. $\left.\mathrm{l}^{-1}\right)$, the cladoceran Bosmina longispina maritima $\left(<10\right.$ ind. $\left.\mathrm{l}^{-1}\right)$ were variable.

$\mathrm{NO}_{3}{ }^{-}$and total $\mathrm{N}$ increased strongly towards the end of the experiment (Fig. 6A,B). Nitrate increased simultaneously with ammonium in all enclosures. $\mathrm{PO}_{4}{ }^{-}$did not

Table 2. Fatty acid composition $\left(\mu \mathrm{g} \mathrm{l}^{-1}\right)$ of phytoplankton in mesocosm enclosures in the middle of the experiment ( 7 July). SAFA: saturated, MUFA: monounsaturated, PUFA: polyunsaturated fatty acids

\begin{tabular}{|lcc|}
\hline Fatty acids & $\begin{array}{c}\text { Treatment (Nodularia } \\
\text { spumigena added) } \\
\text { mean } \pm \text { SD }\end{array}$ & $\begin{array}{c}\text { Control (no N. } \\
\text { spumigena added) }\end{array}$ \\
\hline $14: 0$ & $11.2 \pm 1.3$ & 15.1 \\
$16: 0$ & $119.8 \pm 12.3$ & 14.2 \\
$16: 1 \omega 7$ & $37.9 \pm 4.0$ & 6.9 \\
$18: 0$ & $9.1 \pm 0.6$ & 2.6 \\
$18: 1 \omega 9$ & $12.1 \pm 0.8$ & 3.2 \\
$18: 1 \omega 7$ & $13.7 \pm 0.7$ & 2.3 \\
$18: 2 \omega 6$ & $12.7 \pm 2.7$ & 4.2 \\
$18: 3 \omega 3$ & $50.5 \pm 8.4$ & 5.4 \\
$18: 4 \omega 3$ & $52.6 \pm 11.5$ & 4.3 \\
$20: 3 \omega 3$ & $3.0 \pm 0.2$ & 5.7 \\
$20: 5 \omega 3$ & $6.7 \pm 0.3$ & 6.2 \\
$22: 6 \omega 3$ & $11.1 \pm 1.4$ & 12.0 \\
SAFA & $141.8 \pm 12.0$ & 34.9 \\
MUFA & $68.7 \pm 3.6$ & 15.4 \\
PUFA & $141.0 \pm 22.1$ & 41.0 \\
$\omega 3$ & $126.2 \pm 19.4$ & 35.1 \\
$\omega 6$ & $13.2 \pm 2.7$ & 4.6 \\
Total & $384.2 \pm 40.5$ & 98.6 \\
\hline
\end{tabular}



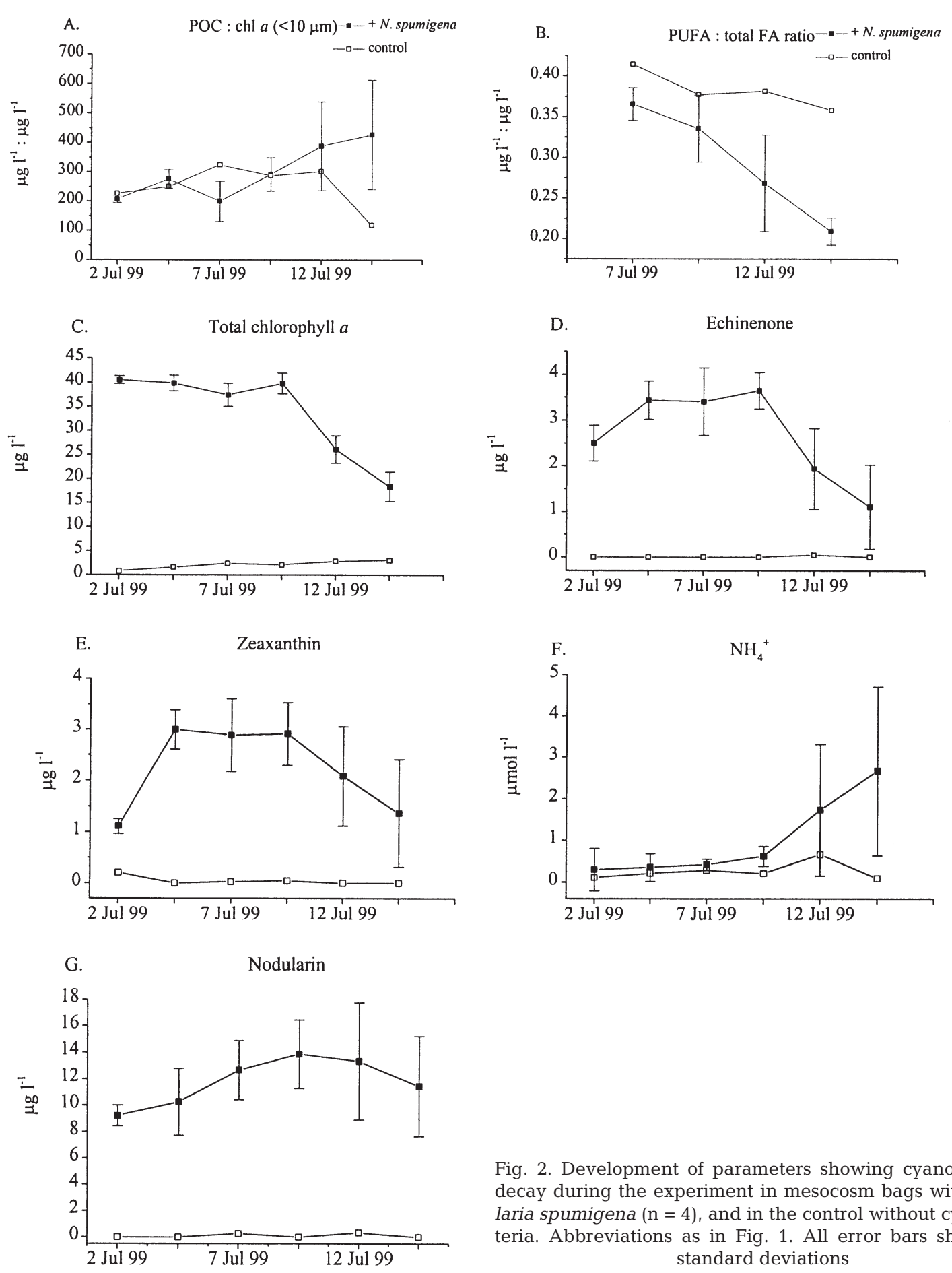

Fig. 2. Development of parameters showing cyanobacterial decay during the experiment in mesocosm bags with Nodularia spumigena $(\mathrm{n}=4)$, and in the control without cyanobacteria. Abbreviations as in Fig. 1. All error bars shown are standard deviations

show any clear pattern (Fig. 6C), whereas total P was high in the treatment bags in the beginning of the experiment $\left(53 \pm 0.4 \mu \mathrm{g} \mathrm{l}^{-1}\right)$, but continued to decrease until the end of the monitoring period (Fig. 6D). Total PON and POP were strongly correlated with Nodularia spumigena (PC 1) and showed a clear decrease at the end of the experiment (Fig. 6E,G). Total POC showed the same

pattern (Fig. 6H). POC, PON and POP $(<10 \mu \mathrm{m})$ were closely associated with processes similar in all bags (PC 2), indicating that they developed in a similar pattern in all bags (data not shown). DON increased in all bags from the middle of the experiment onwards, up to $43 \pm$ $7 \mathrm{mmol} \mathrm{l}^{-1}$ during the last measurement (Fig. 6F). The total N:P ratio increased continuously in all bags and was 

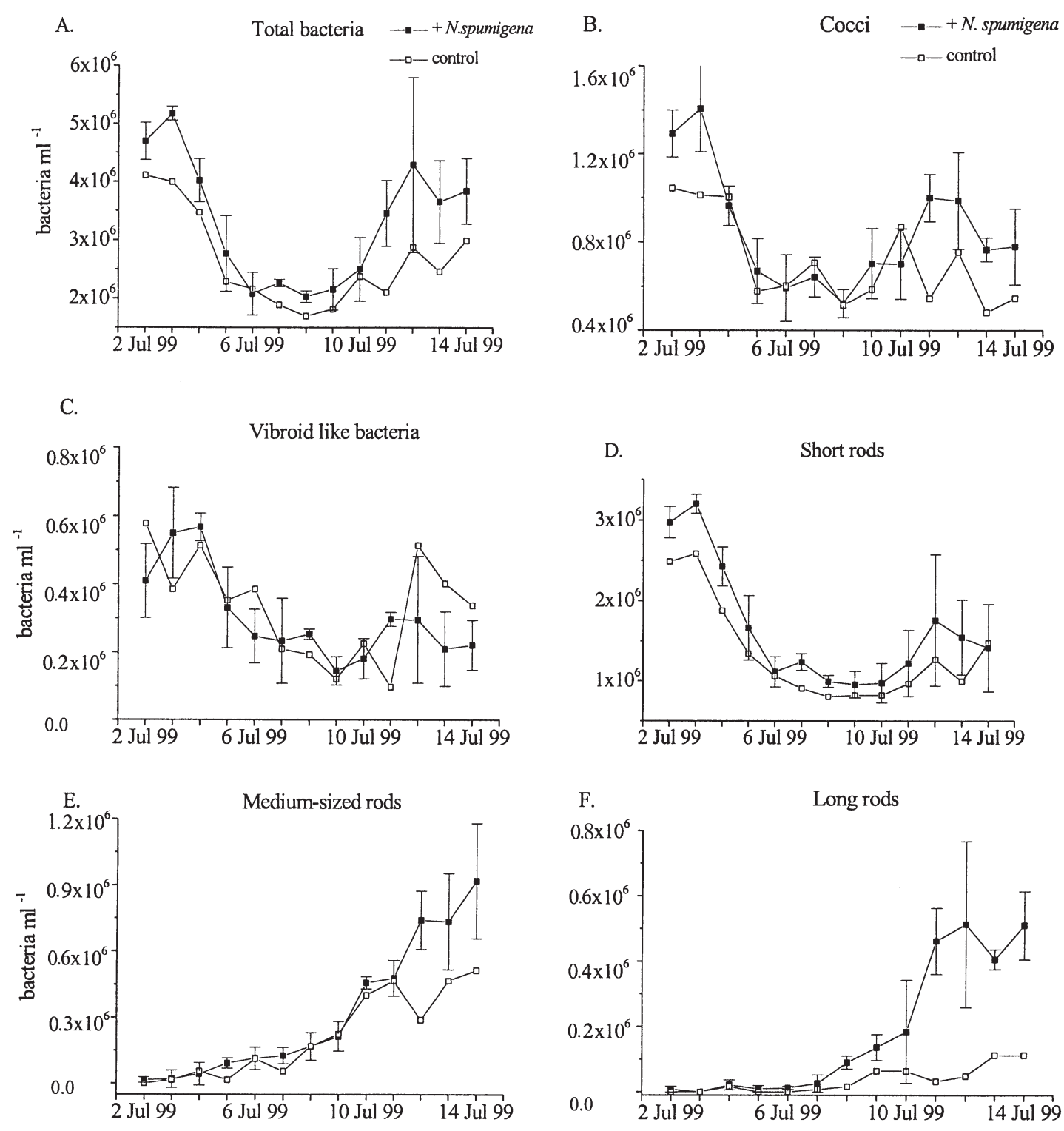

Fig. 3. Abundance of bacteria (ind. $\mathrm{ml}^{-1}$ ). Symbols as in Fig. 2

already above the Redfield ratio in the control enclosure in the beginning of the experiment. In the cyanobacteria bags, the total N:P ratio reached the Redfield ratio on the fifth day of the experiment (Fig. 6I).

\section{DISCUSSION}

\section{Bloom condition}

Hoppe (1981) observed that the decay of Nodularia spumigena was a long process and that the filaments remained suspended in the upper water column for weeks in a stage of progressive decay. By the end of our study, the POC:chl a $(<10 \mu \mathrm{m})$ ratio indicated that the bloom consisted of detritus and was well into the decaying process (Fig. 2A). A POC:chl a ratio below 100 indicates healthy and growing cells (Granéli et al. 1999). A high PUFA:total FA ratio indicates high growth rates (Ahlgren et al. 1992). In our study, the PUFA:total FA ratio as well as total chl a decreased with time, which suggests low growth rates and decay of the cyanobacteria (Fig. 2B,C). Further, a low protein concentration of the seston, among other factors, also indicates bloom decline (Jónasdóttir et al. 1995). In our study, the variation within the protein measurements was too large to find this relationship. 

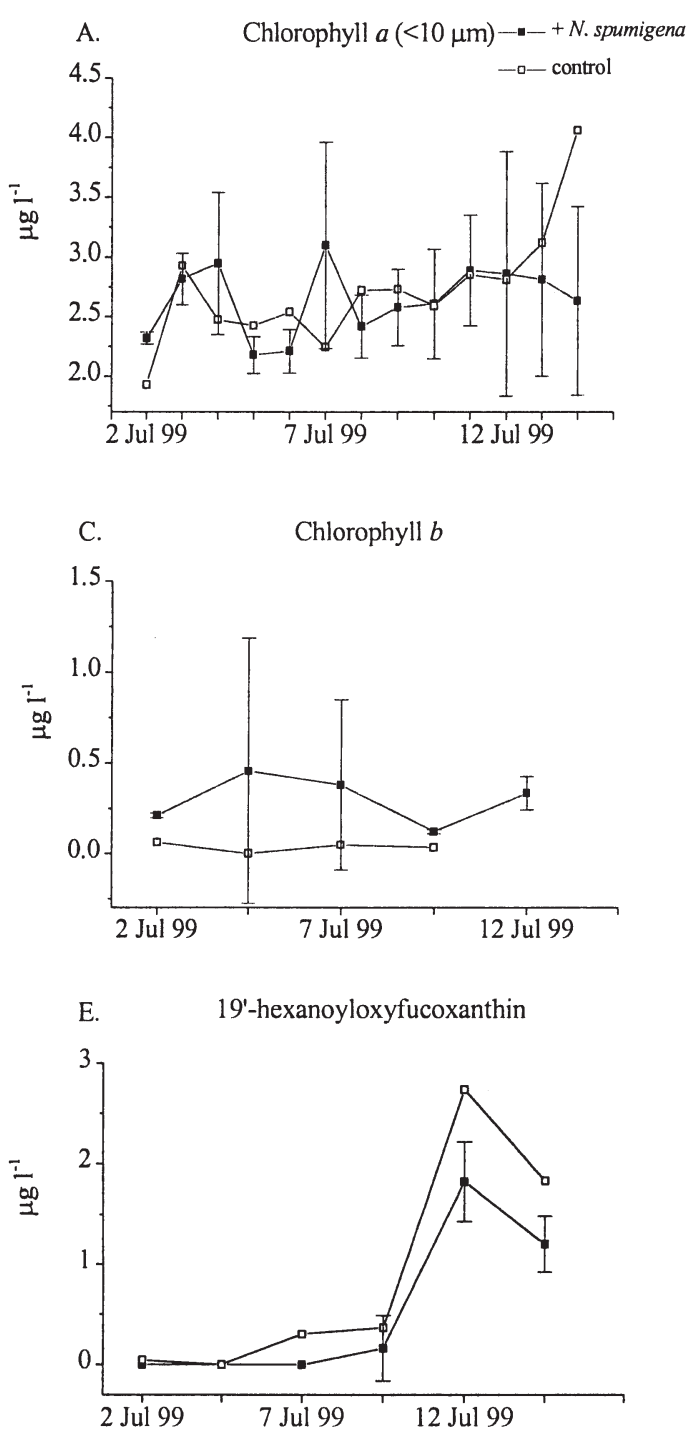

\section{Nutrient concentrations and ratios}

By the end of the experiment, there was almost 3 $\mu \mathrm{mol}$ ammonium $\left(\mathrm{NH}_{4}{ }^{+}\right) \mathrm{l}^{-1}$ in the cyanobacteria bags, indicating that organic nitrogen was leaking into the water from the dying filaments and was decomposed by heterotrophic organisms to ammonium, as suggested by Heinänen et al. (1995). Although ammonium is a major excretory product of aquatic organisms (e.g. crustaceans, ciliates, heterotrohic nanoflagellates), this source is generally minor compared to the one generated by bacteria (Wetzel 1983). The increase in nitrate suggests that nitrification in the enclosures was active. In the Baltic Sea, it has been shown that nitrification occurs during summer down to the chemocline (Enoksson 1986, Rheinheimer et al. 1989).

The high initial total P concentration in the treatment originated most likely from the growth medium of
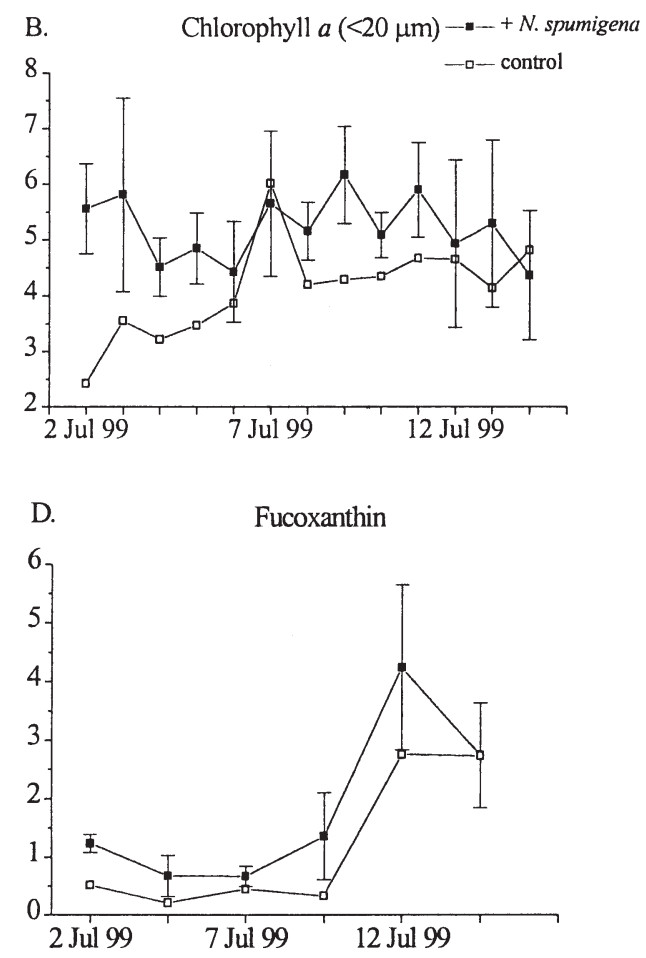

Fig. 4. Phytoplankton pigment concentrations $\left(\mu \mathrm{g} \mathrm{l}^{-1}\right)$. Pigment concentrations were estimated from total phytoplankton in the mesocosm water. Symbols as in Fig. 2

Nodularia spumigena, although the cyanobacteria were carefully filtered in advance in order to remove as much of the medium as possible. Consequently, after the addition of cyanobacteria into the enclosures (Fig. 6I), the total N:P ratio was lower than the ratio recorded during the same time in a nearby pelagic area (17 to 19 , Tvärminne Zoological Station unpubl. data). Heiskanen \& Tallberg (1999) showed that the decay of the cyanobacterial bloom resulted in an increased N:P ratio, which was also observed in our study. Sahlsten \& Sörensson (1989) showed that DON increased simultaneously with the decline of a cyanobacterial bloom. The authors suggested that DON was gradually released from the cyanobacteria and formed a new nitrogen source for planktonic organisms. In our study, DON increased in all enclosures. Generally, DON is mineralised or taken up by bacteria and appears in the water column due to e.g. cell rup- 

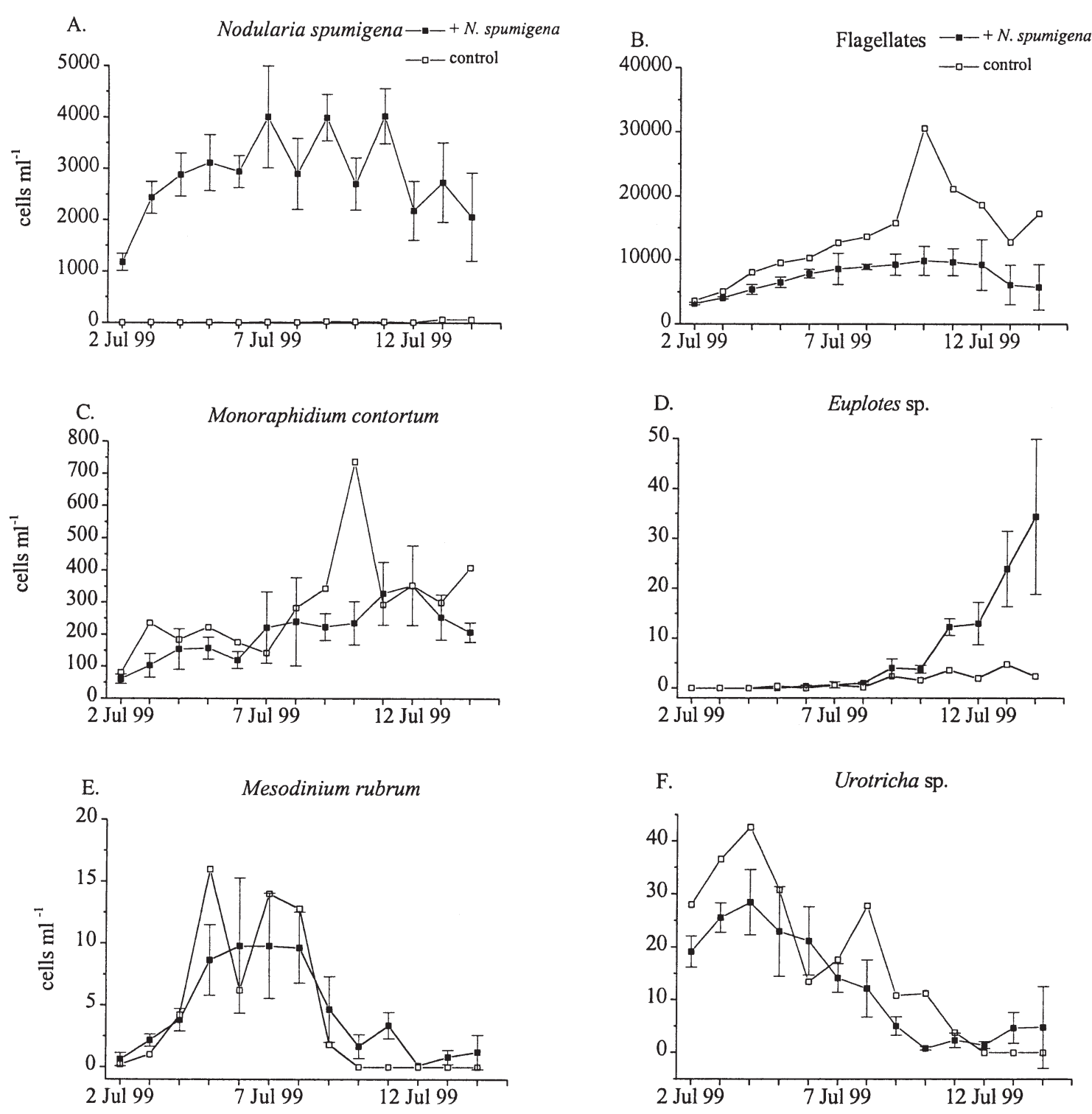

Fig. 5. Phytoplankton and ciliate abundance (cells $\mathrm{ml}^{-1}$ ). Symbols as in Fig. 2

ture caused by grazing (Bronk \& Glibert 1993) or cell lysis caused by viral infections (Procter \& Fuhrman 1990).

\section{Nodularin concentrations}

Survival of crustaceans was high in our experiments (Koski et al. in press), although the highest total nodularin concentration was $19.7 \mu \mathrm{g} \mathrm{l}^{-1}$. No direct harmful effects of nodularin could be detected. Total nodularin concentrations, measured from unfiltered water, remained high during the whole experiment in the cyanobacteria bags. Cyanobacteria toxins have been shown to be very persistent, e.g. Kiviranta et al. (1991) did not detect biodegradation of microcystin in an experiment where toxin was leaking from the cells into the water and remained at high concentrations for $5 \mathrm{wk}$. On the other hand, degradation of hepatotoxins has been detected in other studies (Lahti et al. 1997). We have no data on the dissolved toxins, measured from filtered water. In a recent investigation (S.R. et al. unpubl. data), dissolved nodularin was below the detection limit $\left(0.1 \mathrm{\mu g}^{-1}\right)$ even though toxic Nodularia spumigena was present in the Baltic Sea. In our mesocosm bags, dissolved toxins could have been present due to the small volume of the bags and zero water exchange. Reinikainen et al. (in press) measured low 

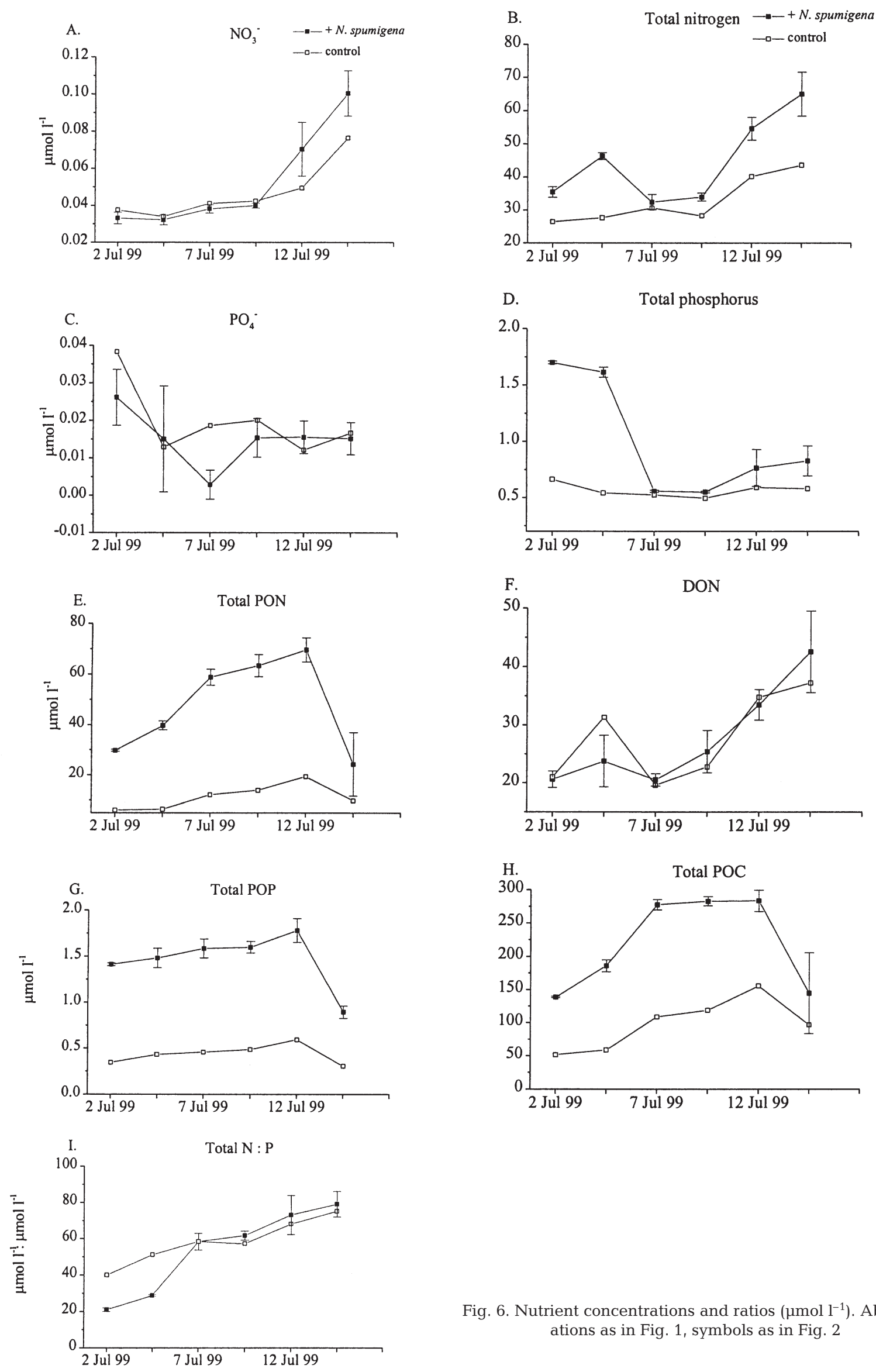

Fig. 6. Nutrient concentrations and ratios $\left(\mu \mathrm{mol} \mathrm{l}^{-1}\right)$. Abbreviations as in Fig. 1, symbols as in Fig. 2 
mortality of Acartia bifilosa, Bosmina longispina maritima and Eurytemora affinis to dissolved nodularin (max. $200 \mu \mathrm{g} \mathrm{l}^{-1}$ ); and DeMott et al. (1991) to microcystin.

\section{Fatty acids}

The major cyanobacterial fatty acids, 16:0, 16:1 and 18:303 (Ahlgren et al. 1992, Vargas et al. 1998), and the cyanobacterial pigments, echinenone and zeaxanthin (Kabata et al. 1992, Piippola \& Kononen 1995), correlated strongly with Nodularia spumigena and associated characteristics (Fig. 1). Few filaments of other cyanobacteria (Anabaena sp., Aphanizomenon flos-aquae, Limnothrix sp.) were observed in the bags. This suggests that the pigments and fatty acids mainly originated from $N$. spumigena. The fatty acid $18: 1 \omega 7$ is common in bacteria, but uncommon in cyanobacteria and phytoplankton (Mayzaud et al. 1989, Volkman et al. 1989). Its concentrations were higher in the cyanobacteria bags than in the control, and therefore it most likely originated from the filamentous bacteria. The main food quality indicators,

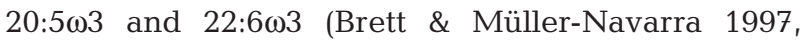
Müller-Navarra et al. 2000), showed high relationships with PC 2, associated with processes similar in all enclosures. This result demonstrates that $N$. spumigena is low in fatty acids that are important for grazers.

The fatty acid concentration was considerably higher than the total chl a concentration in the control. The reason for this was probably that all organisms contain fatty acids (e.g. bacteria, phytoplankton and animals), and were included in the measurement (Fraser et al. 1989, Mayzaud et al. 1989, Volkman et al. 1989, Issik et al. 1999).

\section{Development of flagellates}

The abundance of flagellates (e.g. Chrysochromulina sp., Pyramimonas sp. cryptophytes) was negatively correlated to PC 1, associated with different characteristics of Nodularia spumigena. In the study by Christoffersen et al. (1990), flagellates decreased due to nutrient limitation. This was not likely in our experiment, considering the high concentrations of inorganic phosphorus and nitrogen available in the cyanobacteria enclosures. Instead, predation by microzooplankton and especially by the ciliate Euplotes sp. most likely controlled the flagellates (cf. Vrede et al. 1999). Other factors that may have affected the number of autotrophic flagellates negatively were e.g. low light caused by shading filaments (Christoffersen et al.
1990, Ibelings \& Maberly 1998) or potential antibiotic or -algal substances released by cyanobacteria (Østensvik et al. 1998, Pushparaj et al. 1999).

Based on microscopy, pigment and fatty acid analyses, we aimed at grouping autotrophic groups (pigments) with different flagellates and fatty acids (Tables 1 \& 2). The pigment 19'-hexanoyloxyfucoxanthin originated most likely from the prymnesiophyte Chrysochromulina sp. The major fatty acids of prym-

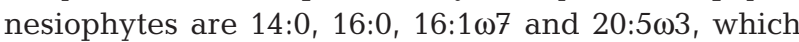
all were abundant in the bags (Zhukova \& Aizdacher 1995). Fucoxanthin originated most likely from different chrysophytes (Pseudopedinella sp., Spiniferomonas sp., Uroglena sp., Table 1), because all the diatoms and dinoflagellates recorded that contained the same pigment were in bad condition. Chrysophytes are characterised by being rich in $\mathrm{C}_{18}$ acids (Ackman et al. 1968), which also were abundant in the enclosures. The major fatty acids of the chlorophycean

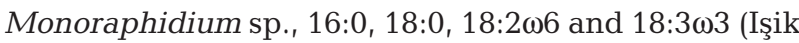
et al. 1999), and chl $b$, were found throughout the experiment and originated most likely from Monoraphidium contortum, a common species in the mesocosms.

\section{Heterotrophic food chain}

Bacterial production is mainly controlled by nutrient concentrations, temperature and grazing during summer (Autio 1992). In our study, nutrient concentrations remained high in the experimental units. The lowest temperature recorded in the enclosures was $13^{\circ} \mathrm{C}$, which is not limiting for bacterial growth (Autio 1992). Predation was in all likelihood the most important factor structuring the population in the enclosures, partly because filamentous bacteria, most likely grazing-resistant, developed, and partly due to the fact that ciliates and bacteria increased simultaneously towards the end of the experiment. This suggests intensive predation by ciliates on the main bacterivores, heterotrophic nanoflagellates (HNAN). The shift in the bacterial community towards filamentous forms strongly suggests that bacteria were imposed a strong grazing pressure (Jürgens \& Güde 1994, Jürgens et al. 1994, 1997).

The abundances of non-filamentous bacteria and short rods can be considered low in the treatment enclosures, especially when taking into account that there probably was plenty of substrate available (Fig. 3B,C,D). In most studies, cyanobacteria have not been found to inhibit bacteria, rather they have been shown to provide good growth conditions for them (Hoppe 1981, Heinänen et al. 1995). Hansen et al. (1986) found that lysis products from dead filamentous 
cyanobacteria may sustain the major part of the bacterial production. A stimulation of the bacterial community could also be explained by the exudation of DON from decaying cyanobacteria. On the other hand, the allelopathic effect of cyanobacteria, e.g. antibacterial activities, has been demonstrated (Østensvik et al. 1998).

Despite prefiltration of the mesocosm water, the abundance of copepodites and other zooplankton was relatively high by the end of the experiment in all the bags (K.S. et al. unpubl.). The zooplankton had presumably grown from eggs and nauplii passed through the mesh during prefiltration (cf. Turner et al. 1999). In the studies by Olsson et al. (1992) and Kivi (1996), copepods efficiently eliminated Urotricha sp. and $M$. rubrum. In our study, the number of Mesodinium rubrum and Urotricha sp. decreased in all the bags (Fig. 5E,F), most likely due to increased predation by nauplii and later by copepodites. The findings of Kivi et al. (1993) support our results; they found the highest protozooplankton growth rates in enclosures treated with $100 \mu \mathrm{m}$ prefiltration and/or with ammonium addition. We suggest that the thigmotactic, i.e. surfacebound, Euplotes sp. thrived in the decaying cyanobacteria community due to the physical support of large algal filaments (Ricci 1989) and by feeding on nanoflagellates (4 to $10 \mu \mathrm{m}$ ). Euplotes sp. may also have escaped predation due to its surface affinity and its protecting lorica (K. Kivi, University of Helsinki, pers. comm.).

Mesozooplankton biomass was low due to prefiltration of the incubated water in the beginning of our experiment. We suggest that, due to lack of predation, microzooplankton were able to suppress HNAN. Consequently, the grazing pressure on bacteria by HNAN remained low but size-selective on smaller-sized bacteria (cocci, vibroid-like bacteria and short rods decreased). We suggest that predation on microzooplankton by mesozooplankton (76 ind. $\mathrm{l}^{-1}$ ), grown from eggs and nauplii, was the main reason for the dramatic decrease of 2 ciliates Mesodinium rubrum and Urotricha sp. at the end of the experiment. Subsequently, HNAN was able to increase slowly, whereas the filamentous bacteria were able to increase rapidly. Although we did not count the HNAN, the POC:chl a ratio $(<10 \mu \mathrm{m})$ increased rapidly towards the end of the experiment, suggesting that heterotrophic organisms peaked by then. Jürgens \& Güde (1994) demonstrated that the removal of Daphnia spp. from a freshwater system resulted in a peak of protozoans, which grazed on the dominating part of the bacterial community. After $3 \mathrm{~d}$, filamentous bacteria had developed, which subsequently dominated the community. We suggest that the same phenomenon occurred in our enclosures.

\section{CONCLUSIONS}

The toxic cyanobacteria Nodularia spumigena started to break down after a few days of the initiation of the experiment in the mesocosm bags. The cells were in bad condition and covered by epiflora and fauna. The PUFA:total FA ratio, as well as the POC:chl a $(<10 \mu \mathrm{m})$ ratio, indicated bloom decay. Ammonium increased due to the decomposition of filaments. A diverse system, seemingly top-down controlled, developed simultaneously with the decay. Planktonic organisms colonised the decaying bloom and used it as a substrate. Several ciliate species and bacteria, probably grazing-resistant, flourished upon the filaments, showing that a decaying bloom is a nutrient-rich substrate to live in. We were not able to detect any direct harmful effects of the stable and high concentrations of nodularin on any of the studied organism groups. The results show that decomposer communities can exist in the presence of toxin. The bacterial biomass increased approximately by a factor of 13 during the experiment in comparison to the biomass at the start, due to the steep increase in bacterial volume. We conclude that these blooms, the occurrence of which is highly dependent on unpredictable factors such as weather conditions, provide a food source for the heterotrophic food chain from bacteria, flagellates and ciliates to crustacean zooplankton, and eventually fish.

Future studies should focus on the ability of different zooplankton groups, including protozoans, to resist cyanobacterial toxins and to use cyanobacteria as food. Also, the possible transfer of toxins from one trophic level to another and the effect of different phases of cyanobacteria blooms on the pelagial carbon flow are largely unknown.

Acknowledgements. We wish to thank R. Autio and 4 anonymous reviewers for constructive and valuable comments on the manuscript. We thank W. Klein Breteler, K. Kivi, H. Kuosa, R. Lignell, M. Reinikainen and A. Visser for discussions. G. Hällfors, E. Kukk and P. Kuuppo helped to get started with the bacteria countings. M. Järvinen helped with phytoplankton taxonomy. E. Salminen, M. Sjöblom and U. Sjölund did lab analyses and microscopy at Tvärminne Zoological Station. I. Topp at the Baltic Sea Research Institute in Rostock performed the HPLC analysis. M. Carlsen at the Danish Institute for Fisheries Research performed the fatty acid analysis. S. Degerholm and L. Keynäs helped us with many practical things. J.E. was financed by the Maj and Tor Nessling Foundation, M.K., K.S. and M.K. by the Walter and Andrée de Nottbeck Foundation, M.V. and K.S. by the Academy of Finland, and S.R. was funded by the EU project 'Preserving the Ecosystem' BASIC (ENV4-CT97-0571). 


\section{LITERATURE CITED}

Ackman RG, Tocher CS, McLachlan J (1968) Marine phytoplankter fatty acids. J Fish Res Board Can 25:1603-1620

Ahlgren G, Gustafsson IB, Boberg M (1992) Fatty acid content and chemical composition of freshwater microalgae. J Phycol 28:37-50

Autio R (1992) Temperature regulation of brackish water bacterioplankton. Ergeb Limnol Arch Hydrobiol Beih 37: $253-263$

Autio R (1998) Response of seasonally cold-water bacterioplankton to temperature and substrate treatments. Estuar Coast Shelf Sci 46:465-474

Bianchi TS, Engelhaupt E, Westman P, Andrén T, Rolff C, Elmgren R (2000) Cyanobacterial blooms in the Baltic Sea: natural or human-induced? Limnol Oceanogr 45:716-726

Brett M, Müller-Navarra DC (1997) The role of highly unsaturated fatty acids in aquatic foodweb processes. Freshw Biol 38:483-499

Bronk DA, Glibert PM (1993) Contrasting patterns of dissolved organic nitrogen release by two size fractions of estuarine plankton during a period of rapid ammonium consumption and nitrite production. Mar Ecol Prog Ser 96: 291-299

Christoffersen K, Riemann B, Hansen LR, Klysner A, Sørensen HB (1990) Qualitative importance of the microbial loop and plankton community structure in a eutrophic lake during a bloom of cyanobacteria. Microb Ecol 20:253-272

DeMott WR, Zhang QX, Carmichael WW (1991) Effects of toxic cyanobacteria and purified toxin on the survival and feeding of a copepod and three species of Daphnia. Limnol Oceanogr 36:1346-1357

Enoksson V (1986) Nitrification rates in the Baltic Sea: comparison of three isotope techniques. Appl Environ Microbiol 51:244-250

Fraser AJ, Sargent JR, Gamble JC, Seaton DD (1989) Formation and transfer of fatty acids in an enclosed food chain comprising phytoplankton and herring (Clupea harengus L.) larvae. Mar Chem 27:1-18

Fuhrman JA (1981) Influence of method on the apparent size distribution of bacterioplankton cells: epifluorescence microscopy compared to scanning electron microscopy. Mar Ecol Prog Ser 5:103-106

Fulton RS (1988) Resistance to blue-green algal toxins by Bosmina longirostris. J Plankton Res 10:771-778

Granéli E, Carlsson P, Turner JT, Tester PA, Béchamin C, Dawson R, Funari E (1999) Effects of N:P:Si ratios and zooplankton grazing on phytoplankton communities in the northern Adriatic Sea. I. Nutrients, phytoplankton biomass, and polysaccharide production. Aquat Microb Ecol 18:37-54

Gulati RD, Siewertsen K, van Liere L (1991) Carbon and phosphorus relationships of zooplankton and its seston food in Loosdrecht lakes. Mem Ist Ital Idrobiol Marco Marchi 48: 279-298

Hair JF Jr, Anderson RE, Tatham RL, Black WC (1998) Multivariate data analysis. Prentice Hall, NJ

Hanazato T, Yasuno M (1987) Evaluation of Microcystis as food for zooplankton in a eutrophic lake. Hydrobiologia 144:251-259

Hansen L, Krog GF, Søndergaard M (1986) Decomposition of lake phytoplankton. 1. Dynamics of short-term decomposition. Oikos 46:37-44

Heinänen A, Kononen K, Kuosa H, Kuparinen J, Mäkelä K (1995) Bacterioplankton growth associated with physical fronts during a cyanobacterial bloom. Mar Ecol Prog Ser $16: 233-245$
Heiskanen AS, Kononen K (1994) Sedimentation of vernal and late summer phytoplankton communities in the coastal Baltic Sea. Arch Hydrobiol 131:175-198

Heiskanen AS, Tallberg P (1999) Sedimentation and particulate nutrient dynamics along a coastal gradient from a fjord-like bay to the open sea. Hydrobiologia 393:127-140

Herbert D, Phipps PJ, Strange RE (1971) Chemical analysis of microbial cells. Methods Microbiol 5B:209-344

Heresztyn T, Nicholson BC (1997) Nodularin concentrations in Lakes Alexandrina and Albert, south Australia, during a bloom of the cyanobacterium (blue-green alga) Nodularia spumigena and degradation of the toxin. Environ Toxicol Water Qual 12:273-282

Hobbie JE, Daley RJ, Jasper S (1977) Use of nuclepore filters for counting bacteria by fluorescence microscopy. Appl Environ Microbiol 33:1225-1228

Hoppe HG (1981) Blue-green algae agglomeration in surface water: a microbiotope of high bacterial activity. Kiel Meeresforsch Sonderheft 5:291-303

Hughes EO, Gorham PR, Zehnder A (1958) Toxicity of a unialgal culture of Microcystis aeruginosa. Can J Microbiol 4: 225-236

Ibelings BW, Maberly SC (1998) Photoinhibition and the availability of inorganic carbon restrict photosynthesis by surface blooms of cyanobacteria. Limnol Oceanogr 43:408-419

Işik O, Sarihan E, Kuşvuran E, Gül Ö, Erbatur O (1999) Comparison of the fatty acid composition of the freshwater fish larvae Tilapia zillii, the rotifer Brachionus calyciflorus, and the microalgae Scenedesmus abundans, Monoraphidium minutum and Chlorella vulgaris in the algae-rotifer-fish larvae food chains. Aquaculture 174:299-311

Jónasdóttir SH, Fields D, Pantoja S (1995) Copepod egg production in Long Island Sound, USA, as a function of the chemical composition of seston. Mar Ecol Prog Ser 119: $87-98$

Jürgens K, Güde H (1994) The potential importance of grazing-resistant bacteria in planktonic systems. Mar Ecol Prog Ser 112:169-188

Jürgens K, Arndt H, Rothhaupt KO (1994) Zooplankton-mediated changes of bacterial community structure. Microb Ecol 27:27-42

Jürgens K, Arndt H, Zimmermann H (1997) Impact of metazoan and protozoan grazers on bacterial biomass distribution in microcosm experiments. Aquat Microb Ecol 12:131-138

Kabata K, Okamoto C, Kikuchi M, Mitsui A (1992) Lipid changes of unicellular cyanobacterium, Synechococcus sp. Miami BG 43511 during the synchronous growth. Proc Faculty Agricult Kyushu Tokai Univ 11:1-5

Kahru M, Horstmann U, Rud O (1994) Satellite detection of increased cyanobacteria blooms in the Baltic Sea: natural fluctuation or ecosystem change? Ambio 23:469-472

Kahru M, Leppänen JM, Rud O, Savchuk OP (2000) Cyanobacteria blooms in the Gulf of Finland triggered by saltwater inflow into the Baltic Sea. Mar Ecol Prog Ser 207:13-18

Kivi K (1996) On the ecology of planktonic microprotozoans in the Gulf of Finland, northern Baltic Sea. PhD thesis, University of Helsinki

Kivi K, Kaitala, S, Kuosa, H, Kuparinen J, Leskinen E, Lignell R, Marcussen B, Tamminen T (1993) Nutrient limitation and grazing control of the Baltic plankton community during annual succession. Limnol Oceanogr 38:893-905

Kiviranta J, Sivonen K, Lahti K, Luukkainen R, Niemelä S (1991) Production and biodegradation of cyanobacterial toxins - a laboratory study. Arch Hydrobiol 121:281-294

Kononen $\mathrm{K}$, Huttunen $\mathrm{M}$, Kanoshina I, Laanemets J, Moisander P, Pavelson J (1999) Spatial and temporal variability of a dinoflagellate-cyanobacterium community under 
a complex hydrodynamical influence: a case study at the entrance to the Gulf of Finland. Mar Ecol Prog Ser 186:43-57

Koroleff F (1979) Meriveden yleisimmät kemialliset analyysimenetelmät. Meri 7:1-60

Koski M, Schmidt K, Engström-Öst J, Viitasalo M, Jónasdóttir $\mathrm{SH}$, Repka S, Sivonen K (in press) Calanoid copepods feed and produce eggs in the presence of toxic cyanobacteria Nodularia Spumigena. Limnol Oceanogr

Kotai J (1972) Instructions for preparation of modified nutrient solution Z8 for algae. Norwegian Inst Water Res Oslo B 11(69):1-5

Lahti K, Rapala J, Färdig M, Niemelä M, Sivonen K (1997) Persistence of cyanobacterial hepatotoxin, microcystin-LR in particulate material and dissolved in lake water. Water Res 31:1005-1012

Lehtimäki J, Sivonen K, Luukkainen R, Niemelä S (1994) The effects of incubation time, temperature, light, salinity, and phosphorus on growth and hepatotoxin production by Nodularia strains. Arch Hydrobiol 130:269-282

Lehtimäki J, Lyra C, Suomalainen S, Sundman P, Rouhiainen L, Paulin L, Salkinoja-Salonen M, Sivonen K (2000) Characterization of Nodularia strains, cyanobacteria from brackish waters, by genotypic and phenotypic methods. Int J Syst Evol Microbiol 50:1043-1053

Lignell R, Heiskanen AS, Kuosa H, Gundersen K, KuuppoLeinikki P, Pajuniemi R, Uitto A (1993) Fate of a phytoplankton spring bloom: sedimentation and carbon flow in the planktonic food web in the northern Baltic. Mar Ecol Prog Ser 94:239-252

Mayzaud P, Chanut JP, Ackman RG (1989) Seasonal changes of the biochemical composition of marine particulate matter with special reference to fatty acids and sterols. Mar Ecol Prog Ser 56:189-204

Meglen R (1992) Examining large databases: a chemometric approach using principal component analysis. Mar Chem 39:217-237

Meyer-Harms B, von Bodungen B (1997) Taxon-specific ingestion rates of natural phytoplankton by calanoid copepods in an estuarine environment (Pomeranian Bight, Baltic Sea) determined by cell counts and HPLC analyses of marker pigments. Mar Ecol Prog Ser 153:181-190

Meyer-Harms B, Reckermann M, Voß M, Siegmund H, von Bodungen B (1999) Food selection by calanoid copepods in the euphotic layer of the Gotland Sea (Baltic proper) during mass occurrence of $\mathrm{N}_{2}$-fixing cyanobacteria. Mar Ecol Prog Ser 191:243-250

Millie DF, Paerl HW, Hurley JP (1993) Microalgal pigment assessments using high-performance liquid chromatography: synopsis of organismal and ecological applications. Can J Fish Aquat Sci 50:2513-2527

Müller-Navarra DC, Brett MT, Liston AM, Goldman CR (2000) A highly unsaturated fatty acid predicts carbon transfer between primary producers and consumers. Nature 403:74-77

Mur LR, Skulberg OM, Utkilen H (1999) Cyanobacteria in the environment. In: Chorus I, Bartram J (eds) Toxic cyanobacteria in water: a guide to their public health consequences, monitoring and management. E \& FN Spon, London, p 15-40

Niemi Å (1975) Ecology of phytoplankton in the Tvärminne area, SW coast of Finland. II. Primary production and environmental conditions in the archipelago and the sea zone. Acta Bot Fenn 105:1-73

Olsson P, Granéli E, Carlsson P, Abreu P (1992) Structuring of postspring phytoplankton community by manipulation of trophic interactions. J Exp Mar Biol Ecol 158:249-266

Østensvik Ø, Skulberg O M, Underdal B, Hormazabal V
(1998) Antibacterial properties of extracts from selected planktonic freshwater cyanobacteria-a comparative study of bacterial bioassays. J Appl Microbiol 84: $1117-1124$

Piippola S, Kononen K (1995) Pigment composition of phytoplankton in the Gulf of Bothnia and Gulf of Finland. Aqua Fenn 25:39-48

Proctor LM, Fuhrman JA (1990) Viral mortality of marine bacteria and cyanobacteria. Nature 343:60-62

Pushparaj B, Pelosi E, Jüttner F (1999) Toxicological analysis of the marine cyanobacterium Nodularia harveyana. J Appl Phycol 10:527-530

Redfield AC, Ketchum BH, Richards FA (1963) The influence of organisms on the composition of seawater. In: Hill MN (ed) The sea. Interscience, Vol. 2. New York, p 26-77

Reinikainen M, Lindvall F, Meriluoto JAO, Repka S, Sivonen K, Spoof L, Wahlsten M (in press) Effects of dissolved cyanobacterial toxins on the survival and egg hatching of estuarine calanoid copepods. Mar Biol

Rheinheimer G, Gocke K, Hoppe HG (1989) Vertical distribution of microbiological and hydrographic-chemical parameters in different areas of the Baltic Sea. Mar Ecol Prog Ser 52:55-70

Ricci N (1989) Microhabitats of ciliates: Specific adaptations to different substrates. Limnol Oceanogr 34:1089-1097

Rolff C (2000) Seasonal variation in $\delta^{13} C$ and $\delta^{15} \mathrm{~N}$ of size-fractionated plankton at a coastal station in the northern Baltic proper. Mar Ecol Prog Ser 203:47-65

Sahlsten E, Sörensson F (1989) Planktonic nitrogen transformations during a declining cyanobacteria bloom in the Baltic Sea. J Plankton Res 11:1117-1128

Sellner K (1997) Physiology, ecology, and toxic properties of marine cyanobacterial blooms. Limnol Oceanogr 42: $1089-1104$

Solórzano L, Sharp JH (1980) Determination of total dissolved phosphorus and particulate phosphorus in natural waters. Limnol Oceanogr 25:754-758

Turner JT, Tester PA, Lincoln JA, Carlsson P, Granéli E (1999) Effects of N:P:Si ratios and zooplankton grazing on phytoplankton communities in the northern Adriatic Sea. III. Zooplankton populations and grazing. Aquat Microb Ecol 18:67-75

Uitto A, Heiskanen AS, Lignell R, Autio R, Pajuniemi R (1997) Summer dynamics of the coastal planktonic food web of SW Finland. Mar Ecol Prog Ser 151:27-41

Utermöhl H. (1958) Zur Vervollkommnung der quantitativen Phytoplankton-Methodik. Mitt Int Verein Theor Angew Limnol 29:117-126

Vargas MA, Rodríguez H, Moreno J, Olivares H, Del Campo JA, Rivas J, Guerrero MG (1998) Biochemical composition and fatty acid content of filamentous nitrogen-fixing cyanobacteria. J Phycol 34:812-817

Volkman JK, Jeffrey SW, Nichols PD, Rogers GI, Garland CD (1989) Fatty acid and lipid composition of 10 species microalgae used in mariculture. J Exp Mar Biol Ecol 128: $219-240$

Vrede K, Vrede T, Isaksson A, Karlsson A (1999) Effects of nutrients (phosphorus, nitrogen, and carbon) and zooplankton on bacterioplankton and phytoplankton-a seasonal study. Limnol Oceanogr 44:1616-1624

Wassman P, Slagstad D (1993) Seasonal and annual dynamics of particulate carbon flux in the Barents Sea. Polar Biol 13: 363-372

Wetzel RG (1983) Limnology. Saunders College Publishing, Orlando, FL

Zhukova NV, Aizdaicher NA (1995) Fatty acid composition of 15 species of marine microalgae. Phytochemistry 39:351-356

Submitted: May 14, 2001; Accepted: October 9, 2001

Proofs received from author(s): April 2, 2002 